\title{
Status of Some Food Quality Prevalent in Niger: A Review
}

\author{
Issoufou Amadou ${ }^{1}$, Halima Oumarou Diadie ${ }^{2}$, Oumarou Samna Soumana ${ }^{1,3}$ \& Abdourahamane Balla ${ }^{2}$ \\ ${ }^{1}$ Laboratory of Food Science and Technology, Faculty of Agriculture and Environmental Sciences, Dan Dicko \\ Dankoulodo University, Maradi, Niger \\ ${ }^{2}$ Research Laboratory of Hygiene and Food Nutrition Science, Faculty of Agronomy, Abdou Moumouni \\ University, Niamey, Niger \\ ${ }^{3}$ Faculty of Agricultural Sciences and the Environment, Boubacar Bâ University, Tillabéri, Niger \\ Correspondence: Issoufou Amadou, Laboratory of Food Science and Technology, Faculty of Agriculture and \\ Environmental Sciences, Dan Dicko Dankoulodo University, BP: 465, Bvd Mohamed VI- ADS Maradi, Niger. Tel: \\ 227-2041-0132. Fax: 227-2041-0133. E-mail: issoufsara@gmail.com
}

Received: April 2, 2019

doi:10.5539/mas.v13n6p135
Accepted: May 5, 2019

Online Published: May 30, 2019

URL: https://doi.org/10.5539/mas.v13n6p135

\begin{abstract}
Food safety considers all risks, chronic or acute, that can make the food harmful to the health of the consumers. Many food-borne hazards come from the lack of hygiene throughout the chain of processing and distribution. The purpose of this work is to address food safety problems as perceived by the consumers in Niger through traditions, stories and experiences. The food produced and consumed in Niger has been the source of collective or individual food poisoning due to the lack of good quality control. Each actor in Niger's food production and distribution chain bears responsibility to take the necessary steps to ensure that the products placed on the market do not pose a risk to the health of consumers.
\end{abstract}

Keywords: food safety, hygiene, quality, niger, foodborne, food poisoning, tradition

\section{Introduction}

Every day, worldwide, people become sick due to the food they consume. These conditions are known as foodborne illnesses and are caused by pathogenic micro-organisms and / or toxic chemicals (Barro et al., 2003; Nascimento et al., 2018). Foodborne diseases are a problem for both developing and developed countries. These diseases add to the burden of care systems; seriously affect infants, young children, the elderly and the sick; create a vicious circle of diarrhea and malnutrition; and harm the economy, national development, and international trade (Mann, and Truswell, 2017). Food quality and food safety are defined separately, even though the two support each other in the same direction to help consumers make their informed decisions (Haghiri, 2016). Food safety refers to the concept that diseases like pathogenic microorganisms, misuse of food additives and contaminants such as chemical or biological toxins and adulteration are prevented, whereas food quality is comprised of a series of consumers' attributes that collectively influence them to put different values on different products at the time of purchase. Some of these attributes are place of origin, freshness, taste, flavour, texture, colour, nutritional value, fat content of foods, the animal welfare, environmentally friendly production, and sustainable farming practices (Haghiri, 2016; Corporation, 2004).

Food safety considers all risks, chronic or acute, that could make food harmful to a consumer. Food safety is nonnegotiable; hence, quality refers to all the other food characteristics that consumers' value. The distinction between safety and quality has policy implications and determines the nature and content of the food control system best suited to identified national objectives (Marchand et al., 2018; Mani et al., 2018). Although governments around the world are doing their best to improve food safety, the prevalence of foodborne diseases remains a major public health problem in all countries. Niger is not an exception and the number of patients with infections and food poisoning in health centers is very high. All these food safety problems are, however, more preventable by simple compliance with hygiene measures. Unfortunately, these measures are often ignored or neglected because the population is largely illiterate and / or uninformed with basic food safety regulations (Nascimento et al., 2018; Fortin et al., 2012).

Dynamic marketing is key to exhibiting a product. However, a good welcome, the cleanliness of the place, an efficient service, respect and good rapport are the parameters that can attract customers. Customers' satisfaction is 
fundamental for the sustainability of the business because it leads to customer loyalty and the positive image of the restaurant/vendor...etc. When the issues of food quality and food safety matter, consumers have no doubt that they will have to pay a premium price to purchase safe and high-quality products. But in the context of Niger, there is a lack of respect for good food safety in Niger, specifically the safety of street foods. The safety of street foods, despite their nutrients content and microbiological content issue, is often not guaranteed (Antoine, 2009). Food poisoning is often linked to either the poor production practices or their inappropriate conservation. This article focuses on the perception of food safety in Niger based on Nigeriens' traditions, stories and experiences. In addition, this article highlights the conditions of foods vendors, restaurants, and family cooks who are bringing foods to consumers in this part of the world.

\section{Hygiene in Food Preparation}

Niger regulation defines hygiene as: "the measures and conditions necessary to control the hazards and to guarantee the properties of a foodstuff for human consumption taking into account the intended use" (Nascimento et al., 2018). Regulations and food chain controls are intended to ensure the hygiene and safety of food from farm to table. These controls aim to prevent food poisoning as well as identify and remove contaminated products from the market. Food production, processing and marketing systems are complex. In many developing countries, such as Niger, the food industry is also very fragmented and dependent on a large number of small producers. Although this industry organization may have socio-economic benefits, the fact that large amounts of food pass through a multitude of intermediary food handlers increases the risk of exposure to poor hygiene, contamination and fraud (Amadou, Gbadamosi, \& Le, 2011; Fleetwood et al., 2018).

Storage conditions during storage and transport also have a significant impact on the quality of food. Failure to comply with temperature and hygrometry conditions may result in the alteration of products and promote the development of pathogenic microorganisms. Each type of food product has different risks because of their nature (origin, composition, sensitivity); their mode of production; their mode of preservation; and how they are prepared and consumed (raw or cooked). Therefore, it is important for the producer to be familiar with the characteristics of their product and knowledgeable of processes for eliminating risks.

In Niger, food hygiene is governed by ORDER N ${ }^{\circ} 93-13$ OF 2 MARCH 1993 which stipulates in article 44: any person who serve in the food chain from farm to plate is required to be highly clean and hygienic in all aspects including the market stage under the responsibility of employer. In addition, article 53 stipulates that: sellers of ready to eat foodstuffs (porridge, pasta, skewers, cakes and others) must protect themselves adequately and ensure the cleanliness of their immediate surroundings (CHPN, 1993).

It is ideal to have a food control system that includes effective enforcement of mandatory requirements alongside training, education and extension programs, as well as incentives for spontaneous enforcement. Preventive approaches, such as Hazard Analysis Critical Control Point System (HACCP), should also be introduced. HACCP has led the food production industry to assume greater responsibility and increase control over food safety risks. An integrated approach provides consumer protection, stimulates agriculture and food processing industries and also national and international food trade (Griffiths \& Schraft, 2017; Yeleliere, Cobbina, \& Abubakari, 2017).

In many countries, including Niger, the food control infrastructure is inadequate, due to limited resources and management deficiencies. Food control laboratories, if they exist, are often poorly equipped and lack properly trained analysts. These deficiencies are aggravated when food control involves the cooperation of several organizations because the lack of overall strategic direction results in inappropriate use of limited resources. Food control systems may also suffer from inadequate enforcement measures (Karippacheril, Rios, \& Srivastava, 2017; Gil et al., 2015). Modern food control systems are based on scientific and transparent decision-making processes and therefore require the availability of suitably qualified and trained people in the fields of food science and technology, chemistry, biochemistry, microbiology, veterinary science, medicine, epidemiology, agronomy, quality assurance, food verification, etc. Food control authorities must understand and appreciate the role of science in the risk-based approach and make use of scientific means (technology and know-how) available in the international community.

\section{Food Poisoning}

The FAO defined food insecurity as 'A situation that exists when people lack secure access to sufficient amounts of safe and nutritious food for normal growth and development and an active and healthy life'. Food must be sanitary; a healthy food must not contain, in dangerous quantities, absorbed toxic products or unwanted contaminants acquired during its preparation, transport or storage (Lorient, 2016; Salama and Radwan, 2005). Coumoul (2015) explained that the industrial age has significantly contributed to the progress of societies while spreading large number of molecules susceptible to toxicity; in addition, a large number of them synthesized 
voluntarily (pesticides) or involuntarily (dioxins) are found at varying levels in our diet and may exert unknown toxic effects because the resulting mixture of these molecules have not been completely studied. All foods may be incriminated in the development of food poisoning, however products from milk, meat, cereals and ovo-products are given attention in this article (Les, 2017; Glanz et al., 2015).

\subsection{The Meat}

Meat is one of the main foods in Niger, but its consumption is not exempt from the risk of food poisoning because quality measures are not guaranteed by the commodities' processors (Vainio, Irz, \& Hartikainen, 2018; Tacher \& Letenneur, 1999). The source of contamination of the meat consumed by Nigeriens may be endogenous or exogenous depending on the cases as reported in this text by witnesses.

It was reported a foodborne outbreak in a family "during the Tabaski (muslims festival), after the slaughter of the sheep and their dismemberment, their heads and feet were recovered for the preparation of malku (a sauce like product of paws and head of small ruminants). A malku preparation follow steps like grilling to remove the hairs and then soaking for a while; the susceptible stage at which the material might have been contaminated that led to toxicity. After cooking the mallku, the meaty part of the small ruminant head becomes very tender and easy detached from the bone. Though, the dish was so tasty that no one could avoid tasting it. Few hours later after eating the malku with bread as breakfast, it was the beginning of a digestion disorder (stomach ache) in the family and collective food poisoning. The family members who ate the food had to line up for toilet (WC) in the night" (Khayeche et al., 2014).

As I do observe in Niamey the weekends (capital of Niger) are busy days for ceremonies and festivities such as weddings and child naming celebrations, requiring many culinary specialties. When it comes to the culinary specialties, one of the strategies used by the chefs (cooks) is to save time by shortening the time of cooking meat using a technique that consists of boiling the meat after seasoning, with paracetamol, an analgesic. Paracetamol is said to soften the meat during cooking. Many people have unknowingly consumed such meals during ceremonies in Niamey and many have appreciated the tenderness of the pieces of meat presented to them on their dishes.

Late in the night at the National Hospital of Niamey a woman brought her three children presenting with symptoms of digestion disorders (stomach ache, diarrhea, vomiting), following the consumption of the meat. The grilled meat was purchased by their father from his usual butcher. A diagnosis of food poisoning matched the clinical signs and the clinical history. Insufficient cooking of meat may lead to food poisonings; indeed, this this case the patients were treated by duty nurse and released from the hospital 48 hours after admission. The duty medical doctor recommended laboratory analysis to identify the germ responsible to avoid any doubt but this was not completed.

One of the habits in Niger is to bring something home and the cheapest and preferred gifts are foods such as grilled meat (Figure 1). In this line, a particular father of four children returned home with grilled meat from his usual seller. Upon arrival at home, the two youngest children (one aged of three and the other six years old) were already asleep. The mother reserved the meat for them until the next morning, packing the meat at ambient temperature overnight. The following day, the two children who did not eat the meat the day before and their sister, consumed the remaining meat. Two hours later, the three children who ate the meat in the morning started to have diarrhea and vomiting.

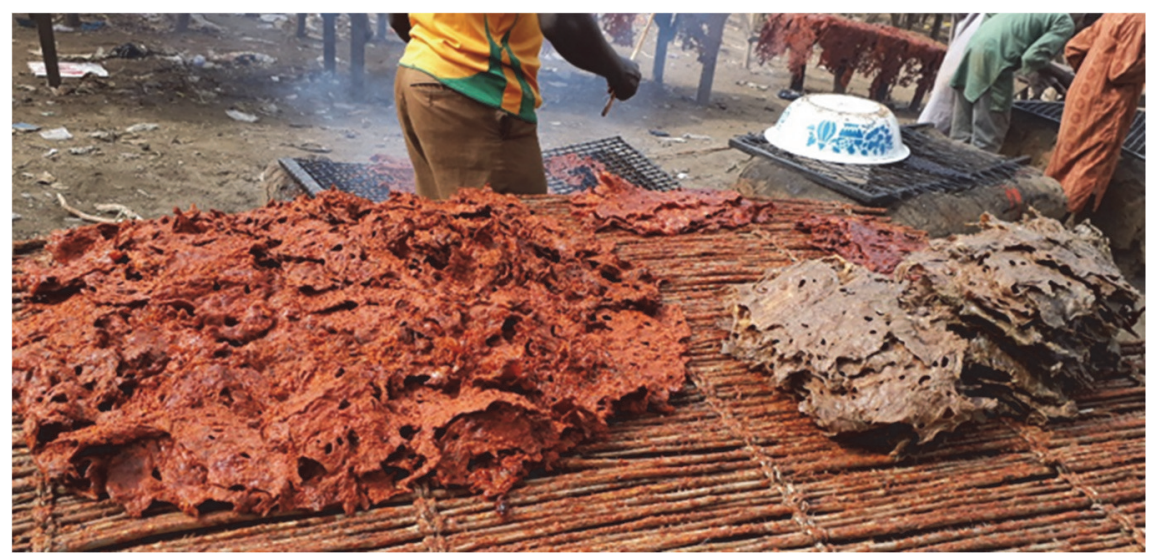

Figure 1. A grilled meat vendor in a local market of Niger, February 2018 by Sara Photo.

Indeed, this meat could be contaminated at the level of the seller, transit to the house, or during the packing at 
home, but those who consumed it right after purchase avoided food poisoning because the microorganisms had not multiplied or produced toxin. Unfortunately, those who consumed it the next day had problems due to the favorable environment for microorganism's proliferation and/or toxin production (Les, 2017).

\subsection{Eggs-Products}

Food security promotes healthy and nutritious food; monitoring of health status and control of transport conditions must be rigorous to ensure good quality of imported eggs; because these products imported into Niger come from the neighboring country, without any information on the quality of the breeding conditions of laying hens that gave these eggs (Zhang et al., 2015) nor information on the packaging and transport conditions prior to entering Niger. However, despite the fact that eggs are stored in cardboard boxes for their physical safety, eggs are often transported from the neighboring country in poor conditions, often on motorcycles, exposed to the sun, which could further affect the safety and quality of these eggs. After arriving in Niger, these eggs continue to be exposed to multiple food safety dangers: the solar radiation which could alter the quality of proteins and vitamins and flies which leave their droppings and secretions on the shell. While Nigeriens may think that the egg shells are waterproof, the pathogenic germs can migrate through this shell and develop in the white and yellow part of eggs, affecting the safety and quality of these eggs (Aendo et al., 2018).

That's why, in the small restaurants along the streets, the cook breaks the eggs out of sight of the customer for fear of rescission (refusal to pay the omelet because it was made from poor quality eggs). If an omelet is made from poor quality eggs, the consumer may end up with food poisoning which could include discomfort, diarrhea and vomiting. However, compared to the definition of food security given earlier, it is wrong to say that imported eggs in this part of world correspond to the healthy and nutritious food that lead a healthy and active life.

A student from our class reported to have witness in Niamey that, twenty-four (24) hours after eating an omelet as breakfast made from such imported eggs, a boy and 20 girls showed signs of allergy (itching, small pimples in the face). Unanimously, it came to conclusion that the discomfort was link to the consumption of food from the eggs. The diagnosis of the physician confirmed that the illness is from the food poisoning or eggs allergen and further laboratory analysis led him to administer the right drugs. Five days later, the symptoms of the boy and his sisters resolved and it remains unknown if the particular family is allergic to eggs or if was just a food poisoning isolated case (Aendo et al., 2018; Nascimento et al., 2018).

\subsection{Dairy Products}

Milk is a complete food, and from a physico-chemical point of view, is a complex food because of its molecular organization, including existing interactions between its various constituents and the variability of its composition which varies based on the species, breed, diet and lactation period. These physico-chemical or biological differences may be responsible for the milk instability, which can be exploited during its transformation into a variety of dairy products such as fermented yogurts, cheeses, creams, butters, and others (Handford, Campbell, \& Elliott, 2016).

It was during a family foyandi (family get-together in local language) organized by a family which is always an occasion of a big eating rendezvous for the guests. Yoghurt, a fermented dairy product is often made for the occasion with different flavors (commercial or fresh fruits) to make it taste sweet and provide variety. Traditionally, people prepare the yoghurt at home where they may not follow good food safety. The foyandi yoghurt is often a big quantity with short time for its processing. That day was particular the yoghurt tasted good and look pleasant, though the quality wasn't in there because people who took it ended with digestion problems such as constipation. This may be justified by the fact that the inoculum (old yoghurt) used was not subject to quality control in the manufacturing process that would judge the biological contamination dose of yoghurt. Similar foodborne infection was reported by the women who used the same yoghurt portion in making the dagué drink (cereal-based food and yoghurt) (Fardet \& Rock, 2018).

Yoghurt is a favorite food of Niger people compared to raw milk, which is much more perishable. An amateur of no experience or training in milk processing made yoghurt (a quantity of about 15 liters) to please her family that she invited at home after returning from a long journey abroad. The lady had prepared all necessary ingredients the same night involved in the process of yoghurt making that she learned from the internet on the spot. The following day early in the morning she added a little sugar and water, vanilla and ice to cool the yoghurt and put the small portion to the refrigerator before taking it to the family for the reunion. In addition, slices of canned pineapple were added to further enhance the flavor. The first people who tasted the yoghurt were her brother and aunt who enjoyed the product. They had drunk significant amounts of it and even took home to other family members who were not at the rendezvous. The day started badly, hours later it was a big disaster in the family "the toilet race" due to stomachaches and diarrhea and any person who took that yoghurt presented the same symptoms. 
This food poisoning was suspected to be caused by the consumption of the yoghurt because the only food as breakfast in that morning. The only excepted people were the dad who was not there because he had a busy day that day and the guests who came after were not served because the yoghurt was replaced with juice and fruit alter run. Having known that the dad who is a medical doctor had automatically concluded that it is a food poisoning. Despite that the origin or the source of the real cause of foodborne infection remained unknown by the family, that is what off the ingredients could be responsible of poisoning or is that during preparation something leaked in? Or because it was taking as breakfast early in the morning; so many questions were asked. Certainly, the return lady from abroad wasn't happy with the event that had prevented her from achieving her goal that is to please her family after a long absence (Les 2017).

\subsection{Cereal Products}

In the city like Niamey capital of Niger republic, bread is one of the most consumed foods and the bakery industry is yet to get to the top of its modernization, that is to the international standards. However, efforts are been made to minimize risk through the implement of elements of hygiene requirement.

This is a story of an internship student who took part in the activities of a local bakery, during his stay he noticed that right form bread manufacture there was a total failure in terms of hygiene of personnel, manufacturing equipment, transport and warehouse. The reporter said that the work men in bread processing do not wear work clothes, gloves and neither mouth cover or head cap. The oven, the mixer and kneader are not cleaned daily, the same as the flour measuring cup. The bakery freezer was turned to the personnel's items storage place instead of factory materials. There was no respect of hygiene at that particular bakery during the handling of the dough such as: the worker can touch his cell phone put it back in the pocket, smoke the cigarette with no worries and carry on the Kneading the dough or removing the bread from the mussels. Worse the distribution of the bakery products is also deplorable; it could be seen bread been transported in the boot of a taxi often very dirty, bear hands are passing touching the product throughout the chain of distribution, which would promote contaminations. At the sale spots, breads are often exposed to flies and dust, in the rare cases bags are used, which are sometime unsaved because they are second hand bags, in fact without washing. Worse, the retailer's practice is that they allow customers/buyers to have opportunity to fiddle with bread to choose the right baguette, showing how this could lead to the development of pathogenic mold responsible for food poisoning (Salama and Radwan, 2005). This is an alarming and very worrying situation that must call the attention of the local authorities because it is a chain of direct contamination which may have huge consequences on public health if appropriate measures are not taken; especially, bakery product are known as ready to eat foods, they do not go through any washing after manufacturing and distribution.

Agadez is historical city located in desert part of Niger where a tradition called Bianou, a party celebrated every year a week after the Tabaski (muslim festival) by the Touareg community. Indeed, during this celebration varieties of foods are made, such as the gourassa, a traditional bread made from wheat flour using tenderou (berried jar as oven); in addition, different sauces accompanied the gourassa. As matter of fact, the process of gourassa involved several women from the community grouped in form of committee of gourassa preparation. Most of the stapes of making a bread dough are followed with exception of some ingredients added until the dough is ready for oven that is pasted on the wall of the tenderou up to readiness of the loafs in forms of balls. The same committee is to make the sauces that goes with the gourassa using availably local vegetable of the season. However, it can be seen that in most cases, the meat meant for the sauce is exposed to flies waiting to finish the gourassa and then carry on with the sauce process. It is a tradition the whole process ends around the afternoon, also time for degustation and enjoying the meals of Bianou day. The report must have said that the people who ate the meal had diarrhea the following day, meaning that they were food poisoning; likely due the fact that the poor hygiene conditions noted during the preparation especially of the gourassa sauce.

Usually, students from the universities spend their holidays called "grandes vacances" in different localities of the country. Zinder city in years back, a first-year medical student spent his holidays with his family. Traditionally, Fura a drink made from millet or sorghum is common among the regular meals (lunch) in various family in that locality of Niger (Okiki et al., 2018). It is a tradition that Fura is consumed with nono (milk) to give Fura da nono (Fura drink); that day the nono was purchased from a Fulani saleswoman who was passing by the door of the house. The narration said that it was so delicious that he consumed almost the whole calabash (traditional recipient containing the Fura) and the consequences were some time later he started with constipation followed by the stomach pain then running diarrhea. At the end the student had to be admitted to the hospital for emergency treatment. After diagnosis the doctor came to realize that the patient was victim of food poisoning probably from the improper nono. Quick recovery was noticed from the patient who learn that quality of food or food ingredient must be considered before consumption of any food (Les, 2017). 


\section{Fruits and Vegetables}

Fruits and vegetables and their related products are known to be very perishable biological commodities, that need particular attention by the society to protect their people. On the other hand, companies try always to maintain business gain by all means; thus, in that line some of these companies' practices sale of perished products with false nutrition facts information in complicities with traders from both parties. This is mostly happened in nations with poor quality control system or countries in difficulties. In some cases, local famers or traders are responsible of causing food poisoning in chain (Figure 2).

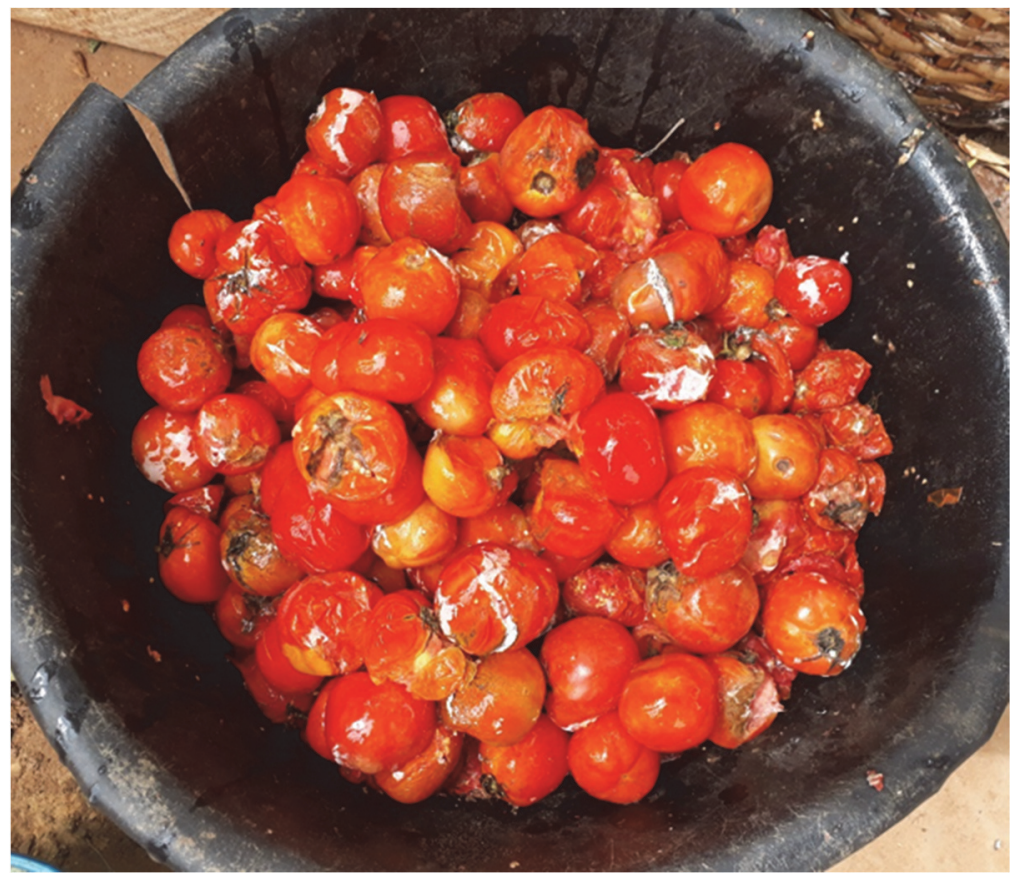

Figure 2. Decay tomatoes for sale (used for stew making by some street foods vendors) Niger, July 2018 by Sara Photo

This story was brought out by a medical worker at national hospital of Niamey some couple of years ago, while on duty that day a crowd of patients invaded the hospital emergency care facilities. They were 26 children (under 15 years) and 6 women, they all consumed powder néré (a meal made from Parkia biglobosa pulp) (Sankhon et al., 2014). It was panic, the duty team alerted the heads of the various services and other specialists for help to care of those patients and they responded with helping hand like any good medical care person. First all emergency concerning those cases were clear up before conducting a thorough clinical examination. The primary symptoms were vomiting from the whole patients and convulsions, they were managed through intravenous care in some of the cases with anticonvulsant drugs. Based on symptoms specialists suspected to diagnose botulism (a toxin released by pathogenic microorganism Clostridium botilinum) (Coumoul, 2015; Qadri, Yousuf, \& Srivastava, 2015; Tafani et al., 2014). After stabilization of the patients, samples from vomiting were analyzed by LANSPEX (National Laboratory of Public Health and Expertise) and others samples were sent to Europe for analysis; though, thorough clinical examination was unable to found nothing more at that time. Furthermore, one of the patients pass away before reaching the hospital plus the second one who unfortunately did not respond to the anticonvulsants drug administered. Thus, the remaining others got released from the hospital 48 hours after. The next day a team from LANSPEX and local authorities rushed to the village where they were brought from to investigate the case. Interrogations/investigation showed that a certain number of elements such as the chain of particular food purchase up to the consumption did not track any positive result at beginning. Though, toward the end of that particular day of the investigation a useful information came up on how the head of the family transported the food back to his home from the market. The report said that the man has a big family and then he needed to use a big bag to carry the markets goods he bought, question after question it came to the notice that the empty bag used was originally meant to transport chemical fertilizers to farm. In conclusion the samples from the particular bag showed positive with Clostridium botulinum test both from LANSPEX and Europe laboratory results.

Countries with poor facilities and lack of rigorous laws or application of those laws suffer from poor food quality control and Niger is one of theme even though in recent years considerable efforts are been made to improve such 
conditions. Cooking oil is like salt, almost found or used in all families. Oxidation stability is often the most qualified measure to guaranty to some extend the quality of cooking oil sold in a country (Jin et al., 2013; Tafani et al., 2014). Years back in Niger there was witnesses that were all over the news and the medical centers alerted the authorities of the various cases of their patients complaining from having oil traces in their stools. This problem leaks with the consumption of the cooking oil sold on the market, that is unusual. The public opinion was rapidly alerted, various organizations started to call for action to stop it. However, the health authorities revealed after investigations that poor-quality cooking oil was been sold on the market, and immediate action was taking to removed out the remaining stocks on the market (Les, 2017; Monfared, Khorakian, Shirazi, \& Maharati, 2019; Unnevehr, 2015).

\section{Conclusion}

The best way to guarantee food safety is to be well informed about the basic principles of food production and hygiene at home or elsewhere. Food safety is only ensured if the responsibility is shared by all stakeholders. the food chain, from the professional to the consumer. Throughout the food chain, many procedures and control mechanisms are implemented to ensure that the food that comes to the consumer's table is safe for consumption and that the risks of contamination are minimized. This, one must be aware that zero risk does not exist and that legislation and control systems cannot protect people entirely against people who have criminal intentions. It is the responsibility of the competent authorities to use the relevant information to assess the level of risk associated with imported or locally produced commodities.

\section{Acknowledgements}

Authors are grateful to Dr Melody J. MAXWELL for his assistance that improve this work.

\section{References}

Aendo, P., Netvichian, R., Tippayalak, S., Sanguankiat, A., Khuntamoon, T., Songserm, T., \& Tulayakul, P. (2018). Health risk contamination of heavy metals in yolk and albumen of duck eggs collected in central and western Thailand. Biological Trace Element Research, 184(2), 501-507. https://doi.org/10.1016/j.envres.2011.05.013

Amadou, I., Gbadamosi, O. S., \& Le, G. W. (2011). Millet-based traditional processed foods and beverages-a review. Cereal Food World, 56(3), 115-121. https://doi.org/10.1094/CFW-56-3-0115

Antoine, J. M. (2009). Fonctionnalité des aliments : un concept à redéfinir? Cahiers de Nutrition et de Diététique, 44, 113-116. https://doi.org/10.1016/j.cnd.2009.02.004

Barro, N., Cheik, A. T., Ouattara, Philippe, A. N., Aboubakar, S. O., \& Alfred, S. T. (2003). Evaluation de la qualite microbiologique de quelques aliments de rue dans la ville de ouagadougou au Burkina Faso. Cahiers d'études et de recherches francophones / Santé, 12(4), 369-374. Retrieved from http://www.bdsp.ehesp.fr/Base/278654/

CHPN (1993). Articles 44 et 53 du chapitre 3: Hygiene des denrées alimentaires code d'hygiène publique du Niger (CHPN). Jl Offi $\mathrm{n}^{\circ}$ sp. 7 mai 1993.

Corporation, I. R. (2004). Consumer Perceptions of Food Safety and Quality; Agriculture and Agri-Food Canada: Winnipeg, M B, Canada. http://www5.agr.gc.ca/resources/prod/doc/agr/pdf/Canadian_Perceptions.pdf

Coumoul, X. (2015). Toxicologie et alimentation: Nouveaux concepts. Cahiers de Nutrition et de Diététique, 50(6), 6S36-6S41. https://doi.org/10.1016/S0007-9960(15)30016-X

Fardet, A., \& Rock, E. (2018). In vitro and in vivo antioxidant potential of milks, yoghurts, fermented milks and cheeses: A narrative review of evidence. Nutrition Research Reviews, 31(1), 52-70. https://doi.org/10.1017/S0954422417000191. Epub 2017 Oct 2

Fleetwood, J., Rahman, S., Holland, D., Millson, D., Thomson, L., \& Poppy, G. (2019). As clean as they look? Food hygiene inspection scores, microbiological contamination, and foodborne illness. Food Control, 96, 7686. https://doi.org/10.1016/j.foodcont.2018.08.034

Fortin, S., Kameli, Y., Ndiaye, B., Castan, F., Tapsoba, S., \& Martin-Prevel, Y. (2012). Surveillance de la securité alimentaire en milieu urbain au Burkina Faso 2009-2011. Revue d'Epidémiologie et de Santé Publique, 60 Supplement 2, S130. Retrieved from http://www.fao.org/3/a-bd462f.pdf

Gil, M. I., Selma, M. V., Suslow, T., Jacxsens, L., Uyttendaele, M., \& Allende, A. (2015). Pre-and postharvest preventive measures and intervention strategies to control microbial food safety hazards of fresh leafy vegetables. Critical Reviews in Food Science and Nutrition, 55(4), 453-468. https://doi.org/10.1080/10408398.2012.657808. 
Glanz, K., Johnson, L., Yaroch, A. L., Phillips, M., Ayala, G. X., \& Davis, E. L. (2016). Measures of retail food store environments and sales: review and implications for healthy eating initiatives. Journal of Nutrition Education and Behavior, 48(4), 280-288. https://doi.org/10.1016/j.jneb.2016.02.003

Govindarajan, V., \& Trimble, C. (2005). Building breakthrough businesses within established organizations. Harvard Business Review, 83(5), 58-68.

Griffiths, M. W., \& Schraft, H. (2017). Bacillus cereus food poisoning. In Foodborne Diseases (3rd ed.), pp. 395405.

Haghiri, M. (2016). Consumer Choice between Food Safety and Food Quality: The Case of Farm-Raised Atlantic Salmon. Foods, 5(2), 22. https://doi.org/10.3390/foods5020022

Handford, C. E., Campbell, K., \& Elliott, C. T. (2016). Impacts of milk fraud on food safety and nutrition with special emphasis on developing countries. Comprehensive Reviews in Food Science and Food Safety, 15(1), 130-142. https://doi.org/10.1111/1541-4337.12181.

Jin, J., Chen, J., Tian, Y., Zou, L., Wang, L., \& Li, F. (2013). Determination of undecanoic acid and 13-methyltetradecanoic acid connected to the glyceride with internal standard method and its application to the identification of adulteration of illegal cooking oil. Se pu= Chinese Jounal of Chromatography, 31(6), 556560. https://doi.org/10.3724/SP.J.1123.2012.12036

Karippacheril, T. G., Rios, L. D., \& Srivastava, L. (2017). Global markets, global challenges: Improving food safety and traceability while empowering smallholders through ICT. 283-308. https://doi.org/10.1596/978-14648-1002-2_Module11

Khayeche, M., Mhadhbi, M., Gharbi, M., Nasfi, I., \& Darghouth, M. A. (2014). Détection de l'infection par Toxoplasma gondii des ovins abattus dans le gouvernorat de Sousse (centre-est de la Tunisie) à l'occasion de la fête musulmane du sacrifice (Aïd Al-Adha) et analyse des facteurs de risque. Bulletin de la Société de Pathologie Exotique, 107(1), 60-63. https://doi.org/10.1007/s13149-014-0325-6

Les Etudiants (2017). Les rapports des étudiants master 1_nutrition humaine/technologie agro-alimentaire. Dans Eléments de Base et Concept Qualité vol. 2015, $201 \overline{6}$ et 2017. ed. I. Amadou, rapports de cours: Université Abdou Moumouni de Niamey.

Lorient, D. (2016). L'aliment naturel: une réalité ou un mythe?. Cahiers de Nutrition et de Diététique, 51(1), 4047. https://doi.org/10.1016/j.cnd.2015.09.003.

Mani, M. O. T., Amadou, I., Adamou, R., \& Salissou, S. Z. (2018). Contamination potentielle des aliments par des polychlorobiphényles (PCBs): Connaissance du polluant et évaluation de la perception du risque. International Journal of Biological and Chemical Sciences, 12(1), 168-179. https://doi.org/10.4314/ijbcs.v12i1.13

Mann, J., \& Truswell, S. (Eds.). (2017). Essentials of human nutrition. Oxford University Press. ISBN: 9780198752981

Marchand, J., Martineau, E., Guitton, Y., Le Bizec, B., Dervilly-Pinel, G., \& Giraudeau, P. (2018). A multidimensional $1 \mathrm{H}$ NMR lipidomics workflow to address chemical food safety issues. Metabolomics, 14(5), 60. https://doi.org/10.1007/s11306-018-1360-x.

Monfared, M., Khorakian, A., Shirazi, A., \& Maharati, Y. (2019). Identifying of Intrapreneurship Behaviors: Case of Country in Transition Economy. Modern Applied Science, 13(5), 1-12. https://doi.org/10.5539/mas.v13n5p1

Nascimento, R. C., Silva, E. M., \& de São Jose, J. F. B. (2018). Good hygiene practices and microbiological contamination in commercial restaurants. African Journal of Microbiology Research, 12(16), 362-369. https://doi.org/10.5897/AJMR2018.8831.

Okiki, P. A., Adeniji, C. A., Oyetunji, O. A., Yusuf, O. A., \& Peters, O. (2018). Assessment of the physicochemical and bacteriological qualities of Nono-a fermented cow milk. Potravinarstvo Slovak Journal of Food Sciences, 12(1), 26-32. https://doi.org/10.29322/IJSRP.8.9.2018.p8180

Qadri, O. S., Yousuf, B., \& Srivastava, A. K. (2015). Fresh-cut fruits and vegetables: Critical factors influencing microbiology and novel approaches to prevent microbial risks - A review. Cogent Food and Agriculture, 1(1), 1121606. https://doi.org/10.1080/23311932.2015.1121606.

Salama, A. K., \& Radwan, M. A. (2005). Heavy metals (Cd, Pb) and trace elements (Cu, $\mathrm{Zn})$ contents in some foodstuffs from the Egyptian market. Emirates Journal of Food and Agriculture, 34-42. 
https://doi.org/10.9755/ejfa.v12i1.5046

Sankhon, A., Amadou, I., Yao, W., Wang, H., Qian, H., \& Mlyuka, E. (2014). Effect of different heat-moisture treatments on the physicochemical properties of African locust bean (Parkia biglobosa) starches. Journal of Agriculture, Science and Technology, 16(2), 331-342. Retrieved from http://journals.modares.ac.ir/article-236599-en.html

Tacher, G., \& Letenneur, L. (1999). Le secteur des productions animales en afrique subsaharienne des independances à 2020. I. place de l'Afrique subsaharienne dans les échanges mondiaux et évolution du secteur élevage. Revue d'élevage et de médecine vétérinaire des pays tropicaux, 52(3-4), 279-90. Retrieved from https://agritrop.cirad.fr/264449/1/ID264449.pdf

Tafani, C., Ouologuem, M., Lebouteux, M., Sallansonnet, M., De Greslan, T., Taillia, H., \& Renard, J. L. (2014). Botulisme alimentaire une histoire de famille. Revue Neurologique, 170(1), A43. https://doi.org/10.1016/j.neurol.2014.01.165

Unnevehr, L. (2015). Food safety in developing countries: Moving beyond exports. Global Food Secience, 4, 2429. https://doi.org/10.1016/j.gfs.2014.12.001

Vainio, A., Irz, X., \& Hartikainen, H. (2018). How effective are messages and their characteristics in changing behavioural intentions to substitute plant-based foods for red meat? The mediating role of prior beliefs. Appetite, 125, 217-224. https://doi.org/10.1016/j.appet.2018.02.002

Yeleliere, E., Cobbina, S. J., \& Abubakari, Z. I. (2017). Review of microbial food contamination and food hygiene in selected capital cities of Ghana. Cogent Food and Agriculture, 3(1), 1395102. https://doi.org/10.1080/23311932.2017.1395102.

Zhang, W., Pan, L., Tu, S., Zhan, G., \& Tu, K. (2015). Non-destructive internal quality assessment of eggs using a synthesis of hyperspectral imaging and multivariate analysis. Journal of Food Engeering, 157, 41-48. https://doi.org/10.1016/j.jfoodeng.2015.02.013

\section{Copyrights}

Copyright for this article is retained by the author(s), with first publication rights granted to the journal.

This is an open-access article distributed under the terms and conditions of the Creative Commons Attribution license (http://creativecommons.org/licenses/by/4.0/). 